\title{
ORGANIZATIONAL COMMITMENT AMONG NURSES AT NAM DINH GENERAL HOSPITAL
}

\author{
Mai Thi Thu Hang ${ }^{1}$, Hoàng Thị Kim Yến ${ }^{2}$ \\ ${ }^{1}$ Nam Dinh University of Nursing; ${ }^{2}$ Nam Dinh General Hospital
}

\begin{abstract}
Objective: Describe organizational commitment among nurses at Nam Dinh General Hospital and related factors. Methods: The study was conducted from August 2020 to June 2021 with a cross-sectional descriptive study method on 154 nurses working at Nam Dinh General Hospital. Results: The the organizational commitment among nurses was at an average level, accounting for $64.5 \%$ with a mean score of 3,495. Among the components of organizational commitment, the nurse's emotional attachment was at the highest level with mean score of 3,577. Among the factors that affected the nurses' commitment to the organization, the factor of working environment; income and the role of the leaders were the most influential factors. Conclusions: The percentage of nurses with high commitment to the hospital was not as high as the expectation (21.7\%). The result was influenced by various different objective and subjective factors.
\end{abstract}

Keywords: Organizational commitment, Nurses, Hospital, Nam Dinh

\section{INTRODUCTION}

Organizational commitment of workers in general and nurses in particular is one of the powerful modes of operation of organizations in order to gain competitive advantage, work efficiency. This is considered the focus of their work innovative, flexible and continuous measures (Allen, NJ \& Meyer) [1]. Studies on organizational commitment in healthcare facilities showed its positive impact on job performance (Hadjali \& Salimi, 2012) [2]. Healthcare staff in general and nurses in particular are one of the most important resources, a key factor determining the existence and development of any hospital. Nam Dinh Provincial General Hospital is not an exception to that general requirement. Because, the commitment of nurses with work and with the hospital contributes significantly to the quality and efficiency of work; creating the reputation as well as the sustainable development of the hospital. A good commitment may help nurses develop their competency and try their best to contribute to the hospital; at the same time, helping themselves to feel more satisfied and happy with their work. The study was conducted with the aim of describing the level of organizational commitment of nurses at Nam Dinh General Hospital. At the same time, the research results may be the basis to help Nam Dinh University of Nursing foster the necessary psychological qualities for the future human resources of
Cor. author: Mai Thi Thu Hang

Address: Nam Dinh University of Nursing

Email: mtthhang@gmail.com
Received: Jan 06, 2022

Accepted: Feb 25, 2022

Published: Feb 26, 2022 
the hospital in general, Nam Dinh General Hospital in particular, in accordance with the Decree 111/2017/ND-CP, the Decree stipulating the plan of practical training in health sector [3].

\section{PARTICIPANTS AND METHODS}

\subsection{Partcipants and setting}

- Nurses at Nam Dinh Provincial General Hospital.

- Data was collected from October, 2020 to November, 2021.

- Setting: Nam Dinh Provincial General Hospital.

\subsection{Methods}

\section{Study design:}

Cross-sectional descriptive study

Sample size and sampling : Formula for calculating sample size was conducted by estimating the population proportion with relative accuracy.

$$
n=Z_{(1-\alpha / 2)}^{2} \frac{p(1-p)}{d^{2}}
$$

n: Study sample size. level).

$Z_{(1-\alpha / 2)}^{2}=1.962$ (With 95\% confidence

$d=0.05$ (Absolute precision desired).

$p=0.1$ (Percentage of nurses with a level of commitment with the hospital).

Substituting into the formula, study sample size was 139 nurses. In order to prevent a certain percentage of selected nurses from being denied or not able to access, the sample size was increased by $10 \%$. The actual sample size in the study was 154 nurses.

Steps to select a systematic random participant:
Step 1: Make a list of research participants in the study population.

Step 2: Determine the coefficient $\mathrm{k}: \mathrm{k}$ $=\mathrm{N} / \mathrm{n}(304 / 154)$ where $\mathrm{N}$ was the number of individuals in the population, $\mathrm{n}$ was the sample size. Distance in this study $\mathrm{k}=2$

Step 3: Select the first research participant with ordinal number i by drawing or choosing a random number table with a number between 1 and $\mathrm{k}$.

Step 4: Find the next research participants according to the principle that the number of the following participants was equal to the number of the previous participants plus the coefficient $\mathrm{k}$ until the sample size was completed. The particpants with number of $n$ had the ordinal number of $\mathrm{i}+(\mathrm{n}-1) \mathrm{k}$.

\subsection{Measurements and data collection}

The measurement was self-report questionnaire using a part, with some modifications, the questionnaire on the likert scale of organizational commitment of Le Thi Minh Loan [3] about organizational commitment of nurses at the hospital and the related factors.

The questionnaire included 9 questions to exploit specific content about the manifestations of commitment. The questionnaire was tested by the research team for specific levels of reliability as follows:

The questions on the level of commitment with the organization of nurses with the following specific items:

+ Items from 1 to 7: Cronbach's Alpha of emotional commitment was 0.869

+ Items from 8 to 13: Cronbach's Alpha was 0.885 
+ Items from 14 to 18: Cronbach's Alpha of Commitment was 0.898

Cronbach's Alpha level of overall cohesion was 0.937

High, low, medium Commitment classification standards and scoring

In the scale, each item had 5 answer options and was assigned points ( $1=$ Strong disagree; 2 = disagree; 3 = neither; 4 = Agree; $5=$ Strong agree). Thus, the maximum was 5 , the minimum was 1 , the higher the $X$, the higher the nurses' level of commitment to the organization. There were 3 levels of commitment: low commitment, medium commitment, and high commitment.

Low level: mean score of commitment $\leq$ $X$ (full scale) - Standard deviation

High level: mean score of commitment $\geq X$ (full scale) + Standard deviation

Moderate level: mean score of commitment ranged between low and high.

Evaluate the level of emotional commitment of questions (1-7):

With $X$ (full scale) $=3.57$, Standard deviation $=0.53$, Therefore,

+ Low level: mean score of commitment $\leq$ 3.05: Nurses had low emotional commitment to the hospital.

+ Moderate level: $3.05 \leq$ mean score $\leq 4.1$ : Nurses had a moderate emotional commitment to the hospital.

+ High degree: mean score of commitment $\geq 4.1$ : The nurse had a high emotional commitment to the hospital.

Evaluate the level of benefit commitment of questions (8-13)

With $X$ (full scale) $=3.52$, Standard deviation $=0.65$, Therefore,

+ Low level: mean score of commitment $\leq 2.9$ : Nurses had low benefit commitment to the hospital.

+ Moderate level: $2.9 \leq$ mean score $\leq$ 4.18: Nurses had a moderate benefit commitment to the hospital.

+ High degree: mean score of commitment $\geq 4.18$ : The nurse had a high benefit commitment to the hospital.

Evaluate the level of responsibility commitment of questions (14-18):

With $X$ (full scale) $=3.21$, Standard deviation $=0.66$, Therefore,

+ Low level: mean score of commitment $\leq$ 2.6: Nurses had low responsibility commitment to the hospital.

+ Moderate level: $2.6 \leq$ mean score $\leq$ 3.9: Nurses had a moderate responsibility commitment to the hospital.

+ High level: mean score of commitment $\geq 3.9$ : The nurse had a high responsibility commitment to the hospital.

Integrating the emotional commitment, benefit commitment and responsibility commitment of nurses, researcher assessed the level of commitment of nurses to the hospital with 3 levels: low commitment, moderate commitment and highly commitment. A higher $\mathrm{X}$ represented a higher degree of commitment.

With $X$ (full scale) $=3.45$, Standard deviation $=0.53$, Therefore,

+ Low level: mean score of commitment $\leq 2.9$ : Nurses had low commitment to the hospital.

+ Moderate level: $2.9 \leq$ mean score $\leq$ 4.0: Nurses had a moderate commitment to the hospital.

+ High level: mean score of commitment $\geq 4.0$ : The nurse had a high commitment to the hospital. 
Comparative analysis: Compare the mean by independence t-test between 2 groups to find out the difference between 2 groups.

Correlation analysis: The correlation analysis was used determine the relationship between commitment and related factors.

\subsection{Data analysis}

The collected data were processed using SPSS 19.0 software before being analyzed using percentages, mean scores to describe variables according to research objectives.

\section{RESULTS}

\subsection{The emotional commitment of nurses with the hospital}

Table 1. The emotional commitment of nurses with the hospital

\begin{tabular}{|c|c|c|c|c|c|c|c|}
\hline \multirow[b]{2}{*}{ Item } & \multicolumn{6}{|c|}{ Rate \% } & \multirow{2}{*}{$\begin{array}{l}\text { Standard } \\
\text { deviation }\end{array}$} \\
\hline & $\begin{array}{l}\text { Strong } \\
\text { agree }\end{array}$ & Agree & Neither & Disagree & $\begin{array}{c}\text { Strong } \\
\text { disagree }\end{array}$ & Mean & \\
\hline $\begin{array}{l}\text { I am very happy to } \\
\text { continue working in the } \\
\text { hospital. }\end{array}$ & 17.1 & 57.9 & 21.7 & 2.0 & 1.3 & 4.17 & 0.757 \\
\hline $\begin{array}{l}\text { really feel the } \\
\text { hospital's problems as } \\
\text { my own. }\end{array}$ & 4.6 & 46.1 & 46.7 & 0.7 & 2.0 & 3.51 & 0.690 \\
\hline $\begin{array}{l}\text { I feel like "a member } \\
\text { of the family" in the } \\
\text { hospital. }\end{array}$ & 5.3 & 64.5 & 27.6 & 0.7 & 2.0 & 3.70 & 0.669 \\
\hline $\begin{array}{l}\text { I feel I was "emotionally } \\
\text { commitment" to the } \\
\text { hospital. }\end{array}$ & 6.6 & 55.9 & 34.2 & 2.6 & 0.7 & 3.65 & 0.674 \\
\hline $\begin{array}{l}\text { This hospital is full of } \\
\text { people who mean a lot } \\
\text { to me. }\end{array}$ & 9.2 & 55.9 & 32.2 & 1.3 & 1.3 & 3.70 & 0.708 \\
\hline $\begin{array}{l}\text { I have a strong feeling } \\
\text { that I belonged in the } \\
\text { hospital. }\end{array}$ & 4.6 & 28.3 & 59.9 & 5.9 & 1.3 & 3.00 & 0.706 \\
\hline $\begin{array}{l}\text { It would be very } \\
\text { difficult for me to leave } \\
\text { this hospital even if I } \\
\text { wanted to. }\end{array}$ & 6.6 & 28.3 & 56.6 & 6.6 & 2.0 & 3.31 & 0.774 \\
\hline Total & & & & 3.57 & & & 0.53 \\
\hline
\end{tabular}

The data in Table 1 showed that nurses had an average emotional commitment to the hospital $(3.05 \leq$ mean score: $3.57 \leq 4.1)$. However, among the expressions to evaluate emotional commitment, there was still one expression that showed a high level of commitment, which was "I will be very happy to continue working in the hospital" (mean score: 4.17), with the highest percentage of nurses choosing "strongly agree" and "agree" (75\%). 


\subsection{The level of benefit commitment to the hospital}

Table 2. The level of benefit commitment to the hospital

\begin{tabular}{|c|c|c|c|c|c|c|c|}
\hline \multirow[b]{2}{*}{ Item } & \multicolumn{6}{|c|}{ Rate \% } & \multirow[b]{2}{*}{$\begin{array}{l}\text { Standard } \\
\text { deviation }\end{array}$} \\
\hline & $\begin{array}{l}\text { Strong } \\
\text { agree }\end{array}$ & Agree & Neither & Disagree & $\begin{array}{c}\text { Strong } \\
\text { disagree }\end{array}$ & Mean & \\
\hline $\begin{array}{l}\text { My life will be greatly } \\
\text { affected if I leave this } \\
\text { hospital. }\end{array}$ & 7.2 & 44.7 & 39.5 & 7.2 & 1.3 & 3.49 & 0.789 \\
\hline $\begin{array}{l}\text { At this point, working } \\
\text { at the hospital is } \\
\text { necessary for me. }\end{array}$ & 13.8 & 50.0 & 31.6 & 2.6 & 2.0 & 3.71 & 0.811 \\
\hline $\begin{array}{l}\text { I have too few options } \\
\text { to consider leaving this } \\
\text { hospital }\end{array}$ & 22.4 & 27.6 & 44.1 & 4.6 & 1.3 & 3.65 & 0.923 \\
\hline $\begin{array}{l}\text { It is difficult for me to } \\
\text { find a similar job in } \\
\text { another hospital. }\end{array}$ & 20.4 & 23.7 & 48.0 & 7.2 & 0.7 & 3.56 & 0.919 \\
\hline $\begin{array}{l}\text { I will lose many things if } \\
\text { I leave this hospital. }\end{array}$ & 2.6 & 27.6 & 55.3 & 12.5 & 2.0 & 3.16 & 0.750 \\
\hline $\begin{array}{l}\text { I feel I have an } \\
\text { obligation to work hard } \\
\text { for the hospital. }\end{array}$ & 9.9 & 40.1 & 46.7 & 2.6 & 0.7 & 3.56 & 0.735 \\
\hline Mean score & & & & 3.52 & & & 0.65 \\
\hline
\end{tabular}

The results of Table 2 showed that the research study had an average benefit commitment $(2.9 \leq$ mean score: $3.52 \leq 4.18)$. The item "At this time, working at the hospital is necessary for me" had the highest mean score (X: 3.71). The results also showed that the majority of nurses reported "strongly agree" and "agree" (63.8\%), which was also the most appreciated content among the items of benefit commitment.

\subsection{The level of responsibility commitment to the hospital}

Table 3. The level of responsibility commitment to the hospital

\begin{tabular}{|lccccccc|}
\hline \multicolumn{1}{|c}{ Item } & \multicolumn{1}{c}{ Strong } & Rate \% & Noither & Disagree & $\begin{array}{c}\text { Strong } \\
\text { disagree }\end{array}$ & Mean & $\begin{array}{l}\text { Standard } \\
\text { deviation }\end{array}$ \\
\hline $\begin{array}{l}\text { I don't feel it is right to } \\
\text { leave this hospital to } \\
\text { do something more } \\
\text { profitable for me. }\end{array}$ & 4.6 & 25.7 & 56.6 & 10.5 & 2.6 & 3.19 & 0.787 \\
\hline $\begin{array}{l}\text { I will feel guilty if I leave } \\
\text { this hospital. }\end{array}$ & 3.3 & 25.7 & 56.6 & 11.8 & 2.6 & 3.15 & 0.770 \\
\hline $\begin{array}{l}\text { This hospital deserves } \\
\text { my allegiance. }\end{array}$ & 2.6 & 33.6 & 55.9 & 4.6 & 3.3 & 3.28 & 0.739 \\
\hline
\end{tabular}




\begin{tabular}{|c|c|c|c|c|c|c|c|}
\hline \multirow[b]{2}{*}{ Item } & \multicolumn{6}{|c|}{ Rate \% } & \multirow[b]{2}{*}{$\begin{array}{l}\text { Standard } \\
\text { deviation }\end{array}$} \\
\hline & $\begin{array}{c}\text { Strong } \\
\text { agree }\end{array}$ & Agree & Neither & Disagree & $\begin{array}{c}\text { Strong } \\
\text { disagree }\end{array}$ & Mean & \\
\hline $\begin{array}{l}\text { I will not leave the } \\
\text { hospital right now } \\
\text { because I feel I have } \\
\text { a responsibility to } \\
\text { everyone. }\end{array}$ & 5.9 & 30.9 & 55.3 & 5.9 & 2.0 & 3.33 & 0.761 \\
\hline $\begin{array}{l}\text { I owe this hospital a lot } \\
\text { because the hospital } \\
\text { has brought me many } \\
\text { benefits. }\end{array}$ & 3.3 & 29.6 & 51.3 & 9.9 & 5.9 & 3.14 & 0.864 \\
\hline Mean score & & & & .21 & & & 0.66 \\
\hline
\end{tabular}

Table 3 showed that the responsibility commitment of the participants was at an average level $(2.6 \leq$ mean score: $3.21 \leq 3.9)$. The responsibility commitment of nurses to the hospital where they work was shown most strongly through the item: "I will not leave the hospital at this time because I feel I have to be responsible to everyone" with mean score of 3.33; "This hospital deserves my loyalty" with with mean score of 3.28. However, the results showed that the responsibility commitment of the nurses to the organization was only moderate with the average level of 3.21.

\subsection{The level of general commitment to the hospital}

Table 4. The level of general commitment to the hospital

\begin{tabular}{|lccccccc|}
\hline \multicolumn{1}{|c}{ Item } & $\begin{array}{c}\text { Strong } \\
\text { agree }\end{array}$ & Agree & Neither & Disagree & $\begin{array}{c}\text { Strong } \\
\text { disagree }\end{array}$ & Mean & $\begin{array}{c}\text { Standard } \\
\text { deviation }\end{array}$ \\
\hline $\begin{array}{l}\text { I am very happy to } \\
\text { continue working in the } \\
\text { hospital. }\end{array}$ & 17.1 & 57.9 & 21.7 & 2.0 & 1.3 & 3.88 & 0.757 \\
\hline $\begin{array}{l}\text { I really feel the hospital's } \\
\text { problems as my own. }\end{array}$ & 4.6 & 46.1 & 46.7 & 0.7 & 2.0 & 3.51 & 0.690 \\
$\begin{array}{l}\text { I feel like "a member } \\
\text { of the family" in the } \\
\text { hospital. }\end{array}$ & 5.3 & 64.5 & 27.6 & 0.7 & 2.0 & 3.70 & 0.669 \\
\hline $\begin{array}{l}\text { I feel I was "emotionally } \\
\text { commitment" to the } \\
\text { hospital. }\end{array}$ & 6.6 & 55.9 & 34.2 & 2.6 & 0.7 & 3.65 & 0.674 \\
\hline $\begin{array}{l}\text { This hospital is full of } \\
\text { people who mean a lot } \\
\text { to me. }\end{array}$ & 9.2 & 55.9 & 32.2 & 1.3 & 1.3 & 3.70 & 0.708 \\
\hline $\begin{array}{l}\text { I have a strong feeling } \\
\text { that I belonged in the } \\
\text { hospital. }\end{array}$ & 4.6 & 28.3 & 59.9 & 5.9 & 1.3 & 3.29 & 0.706 \\
\hline
\end{tabular}




\begin{tabular}{|c|c|c|c|c|c|c|c|}
\hline \multirow[b]{2}{*}{ Item } & \multirow[b]{2}{*}{$\begin{array}{l}\text { Strong } \\
\text { agree }\end{array}$} & \multicolumn{3}{|c|}{ Rate \% } & \multirow[b]{2}{*}{$\begin{array}{c}\text { Strong } \\
\text { disagree }\end{array}$} & \multirow[b]{2}{*}{ Mean } & \multirow{2}{*}{$\begin{array}{l}\text { Standard } \\
\text { deviation }\end{array}$} \\
\hline & & Agree & Neither & Disagree & & & \\
\hline $\begin{array}{l}\text { It would be very difficult } \\
\text { for me to leave this } \\
\text { hospital even if I wanted } \\
\text { to. }\end{array}$ & 6.6 & 28.3 & 56.6 & 6.6 & 2.0 & 3.31 & 0.774 \\
\hline $\begin{array}{l}\text { My life will be greatly } \\
\text { affected if I leave this } \\
\text { hospital. }\end{array}$ & 7.2 & 44.7 & 39.5 & 7.2 & 1.3 & 3.49 & 0.789 \\
\hline $\begin{array}{l}\text { At this point, working } \\
\text { at the hospital is } \\
\text { necessary for me. }\end{array}$ & 13.8 & 50.0 & 31.6 & 2.6 & 2.0 & 3.71 & 0.811 \\
\hline $\begin{array}{l}\text { I have too few options } \\
\text { to consider leaving this } \\
\text { hospital }\end{array}$ & 22.4 & 27.6 & 44.1 & 4.6 & 1.3 & 3.65 & 0.923 \\
\hline $\begin{array}{l}\text { It is difficult for me to } \\
\text { find a similar job in } \\
\text { another hospital. }\end{array}$ & 20.4 & 23.7 & 48.0 & 7.2 & 0.7 & 3.56 & 0.919 \\
\hline $\begin{array}{l}\text { I will lose many things if } \\
\text { I leave this hospital. }\end{array}$ & 2.6 & 27.6 & 55.3 & 12.5 & 2.0 & 3.16 & 0.750 \\
\hline $\begin{array}{l}\text { I feel I have an } \\
\text { obligation to work hard } \\
\text { for the hospital. }\end{array}$ & 9.9 & 40.1 & 46.7 & 2.6 & 0.7 & 3.56 & 0.735 \\
\hline $\begin{array}{l}\text { I don't feel it is right to } \\
\text { leave this hospital to } \\
\text { do something more } \\
\text { profitable for me. }\end{array}$ & 4.6 & 25.7 & 56.6 & 10.5 & 2.6 & 3.19 & 0.787 \\
\hline $\begin{array}{l}\text { I will feel guilty if I leave } \\
\text { this hospital. }\end{array}$ & 3.3 & 25.7 & 56.6 & 11.8 & 2.6 & 3.15 & 0.770 \\
\hline $\begin{array}{l}\text { This hospital deserves } \\
\text { my allegiance. }\end{array}$ & 2.6 & 33.6 & 55.9 & 4.6 & 3.3 & 3.28 & 0.739 \\
\hline $\begin{array}{l}\text { I will not leave the } \\
\text { hospital right now } \\
\text { because I feel I have } \\
\text { a responsibility to } \\
\text { everyone. }\end{array}$ & 5.9 & 30.9 & 55.3 & 5.9 & 2.0 & 3.33 & 0.761 \\
\hline $\begin{array}{l}\text { I owe this hospital a lot } \\
\text { because the hospital } \\
\text { has brought me many } \\
\text { benefits. }\end{array}$ & 3.3 & 29.6 & 51.3 & 9.9 & 5.9 & 3.14 & 0.864 \\
\hline Total & & & & & & 3.45 & 0.53 \\
\hline
\end{tabular}

Organizational commitment of nurses in the hospital was the sum and average of the levels of Emotional commitment, benefit commitment and Responsibility commitment. The results in Table 4 showed that the level of organizational commitment was at an average level $(2.9 \leq$ mean score: $3.45 \leq 4.0)$. 


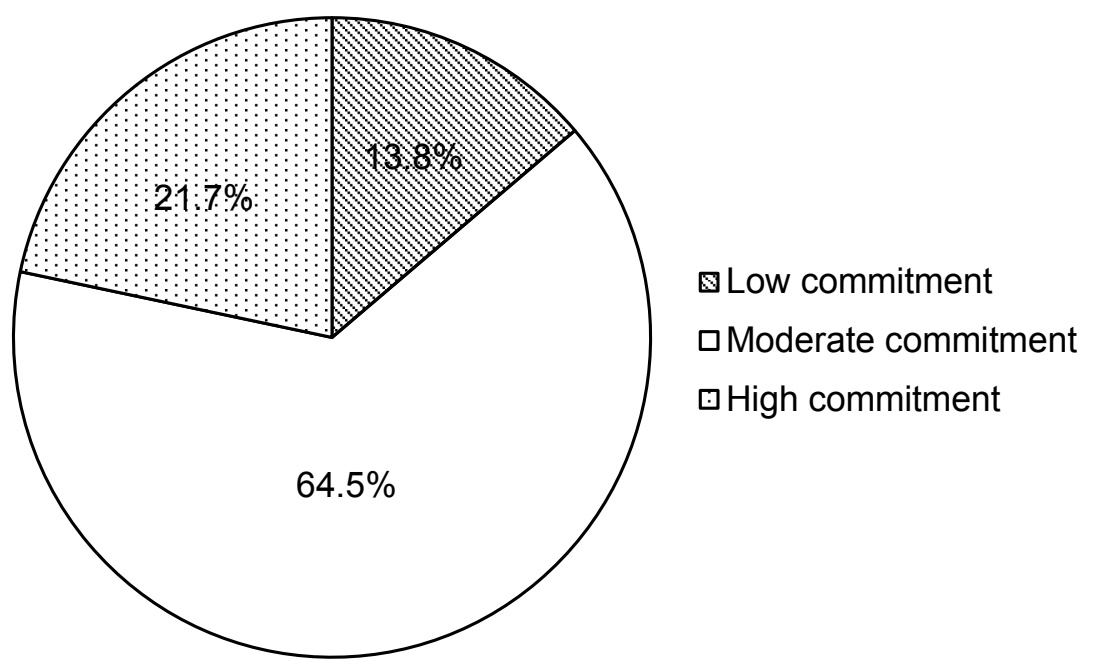

Figure 1. The level of general commitment to the hospital

The figure showed that $21.7 \%$ of participants had a high commitment to the hospital and only one third of the participants had an average commitment to the organization (64.5\%).

\subsection{Factors related to the nurses' commitment to the hospital}

Table 5. Factors related to the nurses' commitment to the hospital

\begin{tabular}{|c|cc|}
\hline \multirow{2}{*}{ Responsibility commitment } & & Correlations $(\boldsymbol{r})$ \\
\cline { 2 - 3 } & Emotional commitment & 0,65 \\
\cline { 2 - 3 } & Benefit commitment & 0.60 \\
\hline
\end{tabular}

\section{DISCUSSION}

Nurses' commitment to the organization at Nam Dinh Provincial General Hospital was the commitment to stay for a long time; contribute their best to the overall development of the hospital where they work. The nurse who is considered to be highly connected to the hospital is not only someone who had affection for her work at the hospital, colleagues, and superiors, but also someone who always recognizes the reality benefits from the Hospital and they really need the work there. Besides, nurses with strong commitment to their hospital will show a high sense of spirit in their work, show responsibility for the results of that work as well as their work performance. That is to say, the employee's commitment to the organization is directly related to and affected by the emotional attachment factors, the employees' interests and responsibilities.

\subsection{Emotional commitment}

In real life, people are not only a combination of logical intelligence but also a synthesis of emotions. Therefore, when working, emotions are definitely an important factor contributing to the 
commitment to the organization in which employees join. The same was with nurses. When they have love, want to stick around for a long time, and want to contribute to the development of the hospital, they often have a high level of emotional attachment to the hospital. In contrast, low emotional attachment is often seen in people who do not want to work long-term in illness; they work for duty, for salary or for some other reason that benefits themselves.

Emotional commitment is not just about feeling happy at work, but also about how each individual feels connected and committed to his or her organization. When nurses have positive emotions, they feel very happy; I really enjoy the work I do at $\mathrm{BV}$; feel that they are dedicated, able to show their own abilities and always want to work at their best. In fact, our research results showed that there were still nurses with positive emotions to the organization, considered the organization as their home and had no intention of moving elsewhere; there were nurses who feel very happy and lucky to work at the hospital, they always worked with a relaxed spirit and wholeheartedly for the patients, for the work they chose. And, there was also a belief that these nurses had a high commitment and long-term commitment to the hospital.

\subsection{Benefit commitment}

Benefit commitment is an important factor in the overall engagement of nurses with the hospital where they work. With the particularity of the profession, there is a lot of pressure related to human health and life; high work intensity; Toxic working environment, many risks of infection. Therefore, like other people doing other jobs, nurses always want to receive benefits commensurate with their efforts. A high degree of benefit commitment is when the nurse really feels that: it will be difficult for them to leave the hospital whether they want to or not, they will be affected or lose many things including: material and spiritual benefits. On the contrary, the nurses feel that it is not difficult for them to find another place to work, can easily leave the hospital when they want without suffering much impact or damage is the manifestation in those with a low level of benefit commitment to the Hospital. Thus, it can be affirmed that low benefit commitment is one of the negative factors affecting work quality and efficiency. They obviously don't have a long-term commitment and are ready to leave when they want to. Through direct exchange, many of the nurses interviewed also answered frankly that: The main benefit is when the income they get is consistent with the effort they put in; is when receiving support and sympathy from colleagues, from superiors; that when they want to go to school to improve their professional qualifications, they will be facilitated; is when annual vacations are arranged to regenerate labor. And, when those needs are not satisfied, the commitment is only "moderate".

\subsection{Responsibility commitment}

The responsibility commitment of nurses to the organization is learned through item on: To what extent do nurses feel they have an obligation to work hard for the Hospital; whether the nurse feels guilty about leaving the hospital; assess the worthiness of the hospital with the loyalty of the nurse and the responsibility of the nurse to the hospital. The nurse herself, if loved, passionate and has a sense of responsibility with their work and the hospital, they will voluntarily comply with the requirements as well as legal 
and ethical principles with that hospital, considering it as a must-do and shoulddo, not just a must-do. At work, the nurse's responsibility will be clearly shown through enthusiasm for the job and compliance with the orders of superiors. The research results were similar to those of Truong Thi Bao Ngoc [6] when many nurses believed that the long-term commitment with the hospital was more or less governed by the benefits brought by the hospital and support from colleagues.

\subsection{Nurses' commitment to the Nam Dinh General Hospital}

Commitment to the organization is the whole commitment to stay long-term, contributing their best to the development of the organization where they work. A nurse who is rated as highly commitment to the Hospital (organization) is not only someone who loves her job, colleagues and superiors, but also someone who has reality benefits from the organization and they really need the work there. Besides, they always show a high sense of spirit at work, show responsibility for the results of their work as well as their performance. That is to say, the commitment of nurses to the organization is directly related to and influenced by factors of their emotional, benefit and responsibility commitment. The results of the study were similar to the recognition and assessment of authors Hoang Thi Thanh Lan [5] and Truong Thi Bao Ngoc [6].

According to the survey results, it was found that there was a strong correlation of the above relationships. Accordingly, the greater the emotional commitment, the greater the benefits and the greater the responsibility, the more it contributes to promoting the high commitment to the organization. At the same time, there was a reciprocal correlation between the levels of commitment, this commitmentwas a premise to tighten and further strengthen the other commitment. Specifically the correlation between responsibility commitment and emotional commitment was relatively high $(r>0.05)$, that was, nurses who had more affection for the hospital may often have more responsibility for their work and vice versa, people who worked more responsibly with the hospital tend to have a higher love and emotional commitment to the hospital. This is an extremely meaningful nursing human resource that every hospital wants. They may not only be dedicated people in their work, bringing high work efficiency, but also always show themselves as cheerful, gentle, responsible people who are always dedicated to the overall development of the hospital. These nurses may also be the ones most likely to stick with the hospital for a long time because of their strong emotional, benefit and responsibility commitment with the hospital.

The obtained research results may be the basis for Nam Dinh Provincial General Hospital in particular and hospitals in general to have a basis to strengthen the factors affecting the level of commitment as well as to have a plan to "retain" their staff. However, it was found that the study still had some limitations as follows:

The first limitation that the sample size was not large and only surveyed in one hospital, so the research results cannot be generalized to other health facilities.

The study did not analyzed in depth the factors affecting organizational commitment components, so the recommendations made may be incomplete and subjective of the researcher. 


\section{CONCLUSION}

The results showed that the percentage of nurses with a low level of commitment to the organization (only $21.7 \%$ had a high level of commitment). However, the mean score of nurses' organizational commitment was quite high (3.5/5). Among the components of organizational commitment, emotional commitment was at the highest level with a rating of 3.57 .

From the research results on factors affecting the level of organizational commitment, it was recommended:

In order to strengthen the commitment of nurses with the organization, it is necessary to pay attention to creating a safe, friendly working environment, with income in accordance with professional capacity.

Managers need to be inspirational, working spirit with the best attitude for employees. Besides professional management, managers should share difficulties with employees; should understand, listen and avoid creating dissatisfaction among employees during the working process.

\section{REFERENCES}

1. Allen. N. J. \& Meyer. J. P. (1990). The Measurement and Antecedents of Affective, Continuance and Normative Commitment to the Organization. Journal of Occupational Psychology. https://doi. org/10.1111/j.2044-8325.1990.tb00506.x

2. Hadjali, H. R., \& Salimi, M. (2012). An Investigation on the Effect of Organizational Citizenship Behaviors (OCB) Toward Customer-orientation:A Case of Nursing Home. Procedia - Social and Behavioral Sciences, .https://doi.org/10.1016/j. sbspro.2012.09.1220.
3. Le Thi Minh Loan (2014). Organizational commitment of workers in non-state enterprises in Bac Ninh province. Research at Vietnam National University.

4. Decree 111/2017/ND-CP- Decree stipulating the plan of practical training in health sector.

5. Hoang Thi Thanh Lan, 2018. Research on the commitment of medical staff to the Thu Duc District Hospital", Master's Thesis in Economics

6. Truong Thi Bao Ngoc, 2019. Commitment with the work of nurses in Bach Mai and related factors", Master thesis in Hospital management

7. Ministry of Health - Ministry of Home Affairs. (2015). Joint Circular 26/2015/ TTLT-BYT-BNV stipulating codes and standards for nursing, midwifery and medical technicians job titles. National database on legal documents. http://vbpl. $\mathrm{vn} /$ bonoivu/Pages/vbpq-van-ban-goc. aspx?ItemID=93949. 